\title{
Effect of Feeding Methods on Modeling of Gut Microbiota of Infants
}

\author{
Kavita M S ${ }^{1}$ and Abdullah Al Anazi ${ }^{2}$ \\ ${ }^{1}$ Asst.Professor of Clinical Nutrition, College of Applied Medical Sciences, King Saud Bin \\ Abdulaziz University for Health Sciences, Riyadh, Kingdom of Saudi Arabia \\ ${ }^{2}$ Dean, College of Applied Medical Sciences, \\ King Saud Bin Abdulaziz University for Health Sciences, Riyadh, Kingdom of Saudi Arabia
}

\begin{abstract}
There is rapid increase in the awareness of composition of microbiota in the gut and its pathogenecity and functionality. The sterile gut of the infant at birth is colonized by diverse microbiota depending upon the immediate environment.Feeding methods has an influence on the development of gut microbiota of the infants as the feeds,feeding equipment and the personnel handling the feeds form the extrinsic factors.Breast milk, being the natural feed for the infant, promotes the growth of more symbiotic bacteria and provide protection against autoimmune disorders and allergic reactions. Whereas feeding methods other than exclusive breast feeding promotes the development of microbiota which can arouse pathological effects with slight disturbances in the gut environment predisposing the infant to many illnesses which may be fatal.
\end{abstract}

Keywords: Infant feeding methods, gut microbiota, breast feeding, formula feeding and pathogenic effects of microbiota

\section{Introduction}

Human gut is an excellent habitat for microorganisms and it is a vibrant fact that the type of the microorganism in the gut is predisposed by the dietary habits and diet. The normal infant gut at birth is sterile. The acquaintance with the environment and maternal interaction makes it a colony of bacteria. Recent research in this field indicated that the gut micro biota developed in the early years have an influence on the development of diet related non communicable diseases in the later years. Changes in the composition of gut enterotypes are found to be associated with the incidence of obesity and Inflammatory Bowel Diseases (IBD). With the changes in gut micro biota due to inf ant feeding habits the infants are susceptible to infectobesity (Di Baise et al.2008). Studies conducted by Mercides de Onis et al. (2010) indicated that there is a very high prevalence of childhood obesity globally.In KSA, even though breast feeding is considered as an important and natural feeding method for infants, mothers adopt different methods of infant feeding (Daifellah et al 2014). Exclusive breast feeding for 6 months after birth is recommended by WHO (Kramer and Kakuma., 2012; James and Lessen,2009). Taking into consideration of the nutritional adequacy and immunological advantages continuation of breast feeding for two years or longer is suggested (WHO,2007and WHO, 2008).Infant feeding practices were categorized by $\mathrm{WHO}$ as, exclusive breast feeding or breast feeding alone, predominant breast feeding and any breast feeding(Wu et al., 2011).

The current review attempts to provide a summary of mechanisms by which different feeding methods influence the development of enterotypes in infants' gut.

\section{Diversity of human gut micro biota}

Soon after the delivery sterile intestinal tract of the infants starts to harbor millions of microorganisms. Positive redox potential of the intestinal milieu of neonates at birth encourages colonization of facultative anaerobes such as Enterobacteriaceae, Lactobacillus etc. Later the colonization of obligatory anaerobes such as Bifidobacterium, Bacteroides, Clostridium etc occur due to the consumption of oxygen by facultative anaerobes (Penders et al., 2006).

A high diversity is the key factor of a micro biota in healthy individuals. Arumugham et al (2011) defined microbiota with similarities in high level organization as enterotypes. Dietary patterns influence the type of enterotypes in the gut. There are three major types of enterotypes viz., Bacteroides, prevotella and ruminococcus enterotypes which were associated respectively with animal fat /protein and carbohydrate based dietary patterns. The basis for enterotypes clustering is unknown and it appears independent of nationality, sex, and age or body mass index.

\subsection{Bacteroides}

Bacteroides is a genus of gram negative bacteria. The major bacteroid found in gut is Bacteroides thetaiotaomicron which are rod shaped, anaerobic, and non-spore forming bacteria. They can be isolated from 
fecal matter (Xu et al.,2003a). It has contributed to postnatal gut development (Xu et al.,2003b).However, it is also a key gram-negative bacterial pathogen with extreme disease causing potential as well as antibiotic resistance.

The anaerobic bacteroides had a major role in the fermentation of carbohydrates, biotransformation of bile acids and other steroids and utilization of nitrogenous substances from the colon. Through anaerobic respiration they produce acetic acid, isovaleric acid, and succinic acid.

$\mathrm{Xu}$ et al(2003b) found the saccharolytic effect of intestinal bacteria and observed that the intestinal bacteria ferments carbohydrates in to Short Chain Fatty Acids(SCFA) leading to the production of acetic acid, propionic acid and butyric acid( Gibsen and Glen,2004). The SCFA produced were utilized as energy sources. However, about $2 \%$ of simple sugars were fermented by the Bacteroides and thus, the main source of energy for bacteroides are the unavailable carbohydrates from the plant fibres and vegetable starches. These include cellulose, arabinogalactan, pectin, xylan, and vegetable starches such as amylose and amylopectin.

\subsection{Prevotella}

Prevotella is the genus of gram negative bacteria. Arumugham et al. (2011) found that the enterotypes prevotella is related to carbohydrates and simple sugars, indicating an association with feeds based on carbohydrates, while Bacteroides enterotypes are associated with animal proteins, amino acids and saturated fats which are the typical components of a formula feed. Wu et al.(2011)indicated that the development and dominance of one enterotype over the other depends on the components of infant feed. The infants who are on feeds rich in protein and animal fats develop Bacteroides bacteria, whereas Prevotella species dominate for those who consume breast milk which is high in carbohydrates (Wu et al.,2011).

\subsection{Ruminococcus}

Ruminococcus is a Gram-positive anaerobic bacterium, belonging to the Firmicutes division (Ludwig et al.,2009). Colonization by R. gnavus was found in infants during the first days of life (Favier et al., 2003 and Joossens et al.,2011) pointed that R. gnavus had an important role in modulating gut inflammatory response at the mucosal surface.

The homeostatic micro biota in the gut can change to heterostatic one due to the changes in the gut ecosystem such as changes in diet, sensitivity to infections or the use of antibiotics (de Vos and Nieuwdorp, 2013).

\section{Feeding habits and development of gut microbiota of infants}

Infancy is a period of sudden environmental change from sterile intrauterine condition to heterogeneous microbial exposure from the immediate environment such as mother's body, the feed and the feeding equipment. Le Huerou et al. (2010) indicated that feeding practices influence the development of gut micro biota composition of infants directly by providing the substrates for bacterial propagation and function. WHO (2008) classified the infant feeding practices as exclusive breast feeding, predominant breast feeding, complementary feeding and bottle feeding as detailed in Table 1.

Table 1.Different infant feeding practices as per WHO (2008)

\begin{tabular}{|l|l|l|l|}
\hline Name & Description & Allows the infant to receive & $\begin{array}{l}\text { Does not allow the } \\
\text { infant to receive }\end{array}$ \\
\hline $\begin{array}{l}\text { Exclusive } \\
\text { breast feeding }\end{array}$ & Allows infant to receive breast milk only & ORS, drops, syrups & Anything else \\
breast feeding & Breast milk as major source of nutrients & $\begin{array}{l}\text { Liquids (like water, water based } \\
\text { drinks, fruit juice), Ritual fluids and } \\
\text { ORS, vitamin and medicine syrups }\end{array}$ & $\begin{array}{l}\text { Anything else } \\
\text { particularly animal } \\
\text { milk, fluids based on } \\
\text { food }\end{array}$ \\
\hline $\begin{array}{l}\text { Complementary } \\
\text { feeding }\end{array}$ & $\begin{array}{l}\text { Allows the infant to receive breast milk } \\
\text { (including milk expressed or from a wet } \\
\text { nurse) with any foods or liquid including non- } \\
\text { human milk or formula. }\end{array}$ & Anything else & NA \\
\hline Bottle feeding & $\begin{array}{l}\text { Any liquid including breast milk or semi- } \\
\text { solid food from a bottle with nipple or teat }\end{array}$ & Anything else & NA \\
\hline
\end{tabular}

Microbial colonization in the gut of infants is influenced by extrinsic as well as intrinsic factors. The feeds as well as the feeding equipment and the immediate surroundings under which the feed were prepared and served or the feeding practices form the extrinsic factors. Various effects of different feeding habits on the proliferation of different species of microorganisms are given in Table 2.

Harmsen et al. (2000) observed that there were variations between the gut microflora of infants following different feeding methods. It was also noticed that bifido bacterial species along with bacteroids and enterobacteria were the dominating micro flora in the gut of infants on exclusive breast feeding. 
Growth of bifido bacreria are often taken as useful indicator of human health under most environmental conditions, based upon the fact that they play important roles in metabolism of amino acids and vitamin production (Hoover, 1993). They also provide immunity (Hentger,1983) and are associated with longevity, antitumor activity(Hughes and Hoover,1991,Hoover,1993) and immune potentiation (Perdigen et al.,1995). The specific immunological and nutrient composition of breast milk enhances the growth of bifido bacteria in the intestine.

A surveillance of infant feeding practices (Mohammed et al., 2004) indicated that exclusive breast feeding was low in many parts of the world. Mohammed et al. (2004) observed that exclusive breast feeding and the mucosal microflora acquired in early infancy protect the infant against autoimmune syndromes such as eczema and atopic allergy (Ogra and Welliver., 2008).Immanuel (1995) commented that 63.2 per cent of the patients reported in a skin clinic with atopic eczema were below two years of age and were followed feeding practices other than breast feeding due to delayed autoimmune responses to food in the digestive tract.

Table 2. Effect of feeding practice on proliferation of gut microbes

\begin{tabular}{|c|c|c|c|}
\hline $\begin{array}{l}\text { Type of feeding } \\
\text { practice }\end{array}$ & Name of microbe & Reference & Peculiarity of gut microbe \\
\hline $\begin{array}{l}\text { Exclusive Breast } \\
\text { feeding }\end{array}$ & $\begin{array}{l}\text { Bifido bacteria } \\
\text { Bifidobacterium breve } \\
\text { B.adolescentis } \\
\text { B.longum } \\
\text { B.bifidum } \\
\text { B.infantis } \\
\text { Bacteroides and Enterobacteria }\end{array}$ & $\begin{array}{l}\text { Balmer and Wharton(1989) } \\
\text { Mackie } \text { et al. } 1999 \\
\text { Harmsen } \text { et al. } 2000 \\
\text { Fanaro } \text { et al. } 2003 \\
\text { Bezirtzoglou } \text { et al. } 2011 \\
\text { Fallani } \text { et al. } 2011\end{array}$ & $\begin{array}{l}\text { Stable and uniform } \\
\text { (Bezirtzoglou et al. 2011) }\end{array}$ \\
\hline $\begin{array}{l}\text { Predominant } \\
\text { Breast feeding }\end{array}$ & $\begin{array}{l}\text { Bifido bacteria } \\
\text { Bifidobacterium breve } \\
\text { B.adolescentis } \\
\text { B.longum } \\
\text { B.bifidum and B.fragilis }\end{array}$ & $\begin{array}{l}\text { Mackie et al } 1999 \\
\text { Harmsen et al } 2000 \\
\text { Fanaro et al } 2003 \\
\text { Fallani et al } 2011 \\
\text { Penders et al } 2006\end{array}$ & $\begin{array}{l}\text { Indicate a wide microbiota } \\
\text { spectrum }\end{array}$ \\
\hline $\begin{array}{l}\text { Complementary } \\
\text { feeding }\end{array}$ & $\begin{array}{l}\text { Bifido bacteria } \\
\text { Bifidobacterium breve } \\
\text { B.adolescentis } \\
\text { B.longum } \\
\text { B.bifidum and B.fragilis }\end{array}$ & $\begin{array}{l}\text { Mackie } \text { et al. } 1999 \\
\text { Harmsen } \text { et al.2000 } \\
\text { Fanaro et al. } 2003 \\
\text { Fallani et al.2011 } \\
\text { Penders et al.2006 }\end{array}$ & $\begin{array}{l}\text { Indicate a wide microbiota } \\
\text { spectrum }\end{array}$ \\
\hline Bottle feeding & $\begin{array}{l}\text { Clostridium sp.s Streptococcus sp.s } \\
\text { Bacillussubtilis Bacteroides } \\
\text { vulgatusVeillonella parvula } \\
\text { Lactobacillus acidophilusE.coli } \\
\text { Pseudomonas aeruginosa } \\
\text { Enterococcus faecalisAtobium }\end{array}$ & Bezirtzoglou et al.2011 & $\begin{array}{l}\text { The counts were higher } \\
\text { than in those of breast fed } \\
\text { infants }\end{array}$ \\
\hline
\end{tabular}

Predominant breast feeding with breast milk and formula milk was the most common type of feeding. Norah (2014) found that about 70 per cent of mothers either ceased predominant breast feeding or shift to complementary feeding or bottle feeding which indicate that majority of the infant's gut have high counts of Atobium ,Bacteroides vulgatus, Bacillus subtilis, Clostridium paraputrificum ,C.perfringens, C.clostridiiforme, C.difficile, C.tertium, E.coli, Enterococcus faecalis , Lactobacillus acidophilus, Pseudomonas aeruginosa, Streptococcus bovis, S.faecalis, S.faecium and Veillonella parvula.

The intestinal micro biota in healthy subjects remains relatively constant but is known to be significantly influenced by physical, chemical and environmental host factors. Alterations to the micro biota may cause abnormal physical conditions or diseases.

Table 3 indicates various effects of microbes found in the gut of infants following feeding practices other than exclusive breast feeding. 
Table 3. Pathogenic effects of microbes found in the gut of infants following feeding practices other than exclusive breast feeding

\begin{tabular}{|c|c|c|c|}
\hline Sl.No. & Name of bacteria & Pathogenic effects & Reference \\
\hline 1. & Atopobium group & Acute retropharyngeal abscess & Kageyama et al.1999 \\
\hline 2. & Bacillus subtilis & Non-pathogenic & Oggioni et al.1998 \\
\hline 3. & Clostridium sp.s & $\begin{array}{l}\text { Gaseous gangrene Necrotizing } \\
\text { enterocolitis GI tract disorders Food } \\
\text { toxicitySudden death }\end{array}$ & De La Cochetière et al.2004 \\
\hline 4. & $\begin{array}{l}\text { Streptococcus bovis } \\
\text { S.faecalis } \\
\text { S.faecium }\end{array}$ & $\begin{array}{l}\text { Endocarditis, Colorectal cancer } \\
\text { Neonatal septicemia and meningitis } \\
\text { Infections in immune deficient infants. } \\
\text { Bacteremia and meningitis }\end{array}$ & $\begin{array}{l}\text { Gerber et al .2006 } \\
\text { Ryan and Ray., } 2004 \\
\text { White } \text { et al. } 2002 \\
\text { Shugui } \text { et al.2008 } \\
\text { Coudron } \text { et al. } 1984\end{array}$ \\
\hline 5. & $\begin{array}{l}\text { Bacteroides } \\
\text { vulgatus }\end{array}$ & Celiac disease & $\begin{array}{l}\text { Ester } \text { et al. } 2014 \\
\text { Federica and Guglielmo., } 2012\end{array}$ \\
\hline 6. & Veillonella parvula & Not considered as a pathogen & Yoshimi et al.1984 \\
\hline 7. & Lactobacillus acidophilus & Allergic reactions & Yoshimi et al.1984 \\
\hline 8. & E.coli & $\begin{array}{l}\text { Gastroenteritis, Urinary tract infections } \\
\text { and neonatal meningitis }\end{array}$ & Yoshimi et al.1984 \\
\hline 9. & Pseudomonas aeruginosa & $\begin{array}{l}\text { Urinary tract infections, Respiratory } \\
\text { system infections, dermatitis, soft } \\
\text { tissue infections, bacteremia, bone and } \\
\text { joint infection and GI tract infection. }\end{array}$ & $\begin{array}{l}\text { Yoshimi et al. } 1984 \\
\text { Balcht and Smith.,2005 }\end{array}$ \\
\hline
\end{tabular}

The major microbes developed in the gut of infants following feeding practices other than breast feeding may produce pathogenic effect on the infant. The main morbific effects observed were allergic reactions, celiac disease, bacteremia, colorectal cancer, endocarditis, food toxicity, gaseous gangrenes, GI tract disorders, gastro enteritis, infections in immune deficient infants, necrotizing enterocolitis septicemia and sudden death. However, Ivarsson et al. (2002) found that the gut microflora developed due to breast feeding had a protective effect against disease development.

\section{Conclusions}

The sterile neonate's gut soon after birth colonizes with diverse microbiota due to the contact with maternal and immediate environment. The mode of feeding the infant affect the development of microbiota within the gut of the infant and many studies indicated that there is difference in the colonization of microbes in the gut of infants on different feeding methods. The feeds, feeding equipment and the personnel who handle the feeds form the extrinsic factors which affect the development of microbes. In breast fed infants, the microbiota is less diverse and nonpathogenic.

The protective action of breast milk seems to rely not only on its specific immune giving components but also on its ability to modulate intestinal microflora composition at primary periods of life. Recently, milk formulae with prebiotics, probiotics, and lacto transferrin have been established to change newborns' microflora composition toward breast-feeding pattern and stimulate immune response. The current review stress the fact that beneficial health-effects of breast milk are indisputably exceptional, has to be natural food of choice for infants in the first 6 months of life. Hence breast feeding should be encouraged and new researches are called for to find specific interactions amongst diet, microbiota composition and health of infants.

\section{References}

[1]. DiBaise JK, Zhang H, Crowell MD, Krajmalnik-Brown R, Decker GA, Rittmann BE. Gut microbiota and its possible relationship with obesity. Mayo Clinic proceedings. Mayo Clinic.2008; 83 (4): 460-2.

[2]. Mercedes de Onis, Monika Blo"ssner, and Elaine Borghi Global prevalence and trends of overweight and obesity among preschool children. Am J Clin Nutr 2010;92:1257-64.

[3]. Daifellah A M Al Juaid,Colin W Binns and Roslyn C Giglia. Breastfeeding in Saudi Arabia:A review. International Breast Feeding Journal.2014.9:1

[4]. Kramer MS,Kakuma R.Optimal duration of exclusive breast feeding.Cochrane Database of American Academy of Pediatrics:Breast feeding and the use of human milk. Pediatrics 2012, 129;e 827-e841

[5]. James DC, Lessen R: Position of the American Dietetic Association: Promoting and supporting breast feeding. J Am.Diet.Assoc.2009,109: 1926-1942

[6]. World Health Organization: Planning guide for national implementation of the global strategy for Infant and young child feeding. WHO, Geneva, WHO 2007

[7]. World Health Organization: Indicators for assessing infant and young child feeding practices-Part 1 definitions.In conclusions of a consensus meeting held 6-8 Novenber2007 in Washington DC,USA.Geneva.WHO Press.2008.

[8]. Wu GD, Chen J, Hoffmann C, Bittinger K, Chen YY, et al. Linking Long-Term Dietary Patterns with Gut Microbial Enterotypes. Science : 2011;334 (6052): 105-108.

[9]. Penders, J., Thijs, C., Vink, C., Snijders, B., Kummeling, I., van den Brandt, P. A., et al. (2006). Factors influencing the composition of the intestinal microbiota in early infancy. Pediatrics. 118, 511-521.

[10]. Arumugam M, Jeroen Raes, Eric Pelletier, Denis Le Paslier, Takuji Yamada, Daniel R. Mende,Gabriel R. Fernandes, Julien Tap, Thomas Bruls, Jean-Michel Batto, Marcelo Bertalan, Natalia Borruel,Francesc Casellas, Leyden Fernandez, Laurent Gautier, 
Torben Hansen, Masahira Hattori, Tetsuya Hayashi,Michiel Kleerebezem, Ken Kurokawa, Marion Leclerc, Florence Levenez, Chaysavanh Manichanh, H. Bjørn Nielsen,Trine Nielsen, Nicolas Pons, Julie Poulain, Junjie Qin, Thomas Sicheritz-Ponten, Sebastian Tims, David Torrents,Edgardo Ugarte, Erwin G. Zoetendal, JunWang, Francisco Guarner, Oluf Pedersen, Willem M. de Vos,Søren Brunak, Joel Dore', MetaHIT Consortium, Jean Weissenbach, S. Dusko Ehrlich and Peer Bork. Enterotypes of the human gut microbiome. Nature; 2011:473(12)174-180.

[11]. Xu,J.,Bjursell,MK.,Himrod,J.,Deng,S.,Carmichael,L.,Chiang,HC.,Hooper,LV and Gordon,JI. A genomic view of the human bacteroides thetaiotaomicron symbiosis.Science;2003a.299:2074-2076

[12]. Xu.,Jian. And Gordon JI.Honor thy symbionts.PNAS:2003b;100(18);10452-10459

[13]. Gibson and Glenn R. Fibre and effects on probiotics (the prebiotic concept). Clinical Nutrition Supplements; 2004: 1 (2): 25-31

[14]. Ludwig W, Schleifer KH, Whitman WB (2009) Revised road map to the phylum Firmicutes.” In: Bergey's Manual of Systematic Bacteriology.2009: 2nd ed., vol. 3 (The Firmicutes) (P. De Vos, G. Garrity, D. Jones, N.R. Krieg, W. Ludwig, F.A. Rainey, K. -H. Schleifer, and W.B. Whitman, eds.), Springer-Verlag, New York. pp. 1-13

[15]. Favier CF, de Vos WM, Akkermans AD. Development of bacterial and bifidobacterial communities in feces of newborn babies. Anaerobe.2003; 9: 219-229

[16]. Joossens M, Huys G, Cnockaert M, De Preter V, Verbeke K, et al. Dysbiosis of the faecal microbiota in patients with Crohn's disease and their unaffected relatives. Gut:2011;60: 631-637

[17]. de Vos WM and Nieuwdorp M.Genomics:a gut prediction.Nature.2013;498:48-49

[18]. Le Huerou- Luron, I., Blat, S., and Boudry, G. Breast- v. formula-feeding: impacts on the digestive tract and immediate and longterm health effects. Nutr. Res. Rev. 2010. 23, 23-36.

[19]. Balmer, SE. and Wharton, BA. Diet and faecal flora in the newborn: breast milk and infant formula. Arch. Dis. Child. 1989; 64, $1672-1677$

[20]. Mackie, RI., Sghir, A., and Gaskins, HR. Developmental microbial ecology of the neonatal gastrointestinal tract. Am. J. Clin. Nutr. 1999:69, 1035S-1045S

[21]. Harmsen, HJ., Wildeboer-Veloo, AC., Wagendorp, AA., Bindels, JG., and Welling, GW. Analysis of intestinal flora development in breast-fed and formula-fed infants by using molecular identification and detection methods. J. Pediatr. Gastroenterol. Nutr. 2000; $30,61-67$

[22]. Fanaro, S., Chierici, R., Guerrini, P., and Vigi, V. (2003). Intestinal microflora in early infancy: composition and development. Acta Paediatr. Suppl.2003; 91, 48-55.

[23]. Bezirtzoglou, E., Tsiotsias, A., and Welling, GW. Microbiota profile in feces of breast- and formula-fed newborns by using fluorescence in situ hybridization (FISH). Anaerobe.2011; 17, 478-482

[24]. Fallani, M., Amarri, S., Uusijarvi, A., Khanna, S., Aguilera, M., Gil, A., et al. Determinants of the human infant intestinal microbiota after the introduction of first complementary foods in infant samples from five European centres. Microbiology.2011; $157,1385-1392$.

[25]. Hoover,DG. Bifidobacteria:activity and potential benefits.Food.Tech.47:120-125

[26]. Hentger, DJ. Role of the intestinal microflora in host defense against infection. In Human Intestinal Microflora in Health and Disease ed.1983. Hentges, Academic Press.

[27]. Hughes, D.B. and Hoover, D.G. (1991) Bifidobacteria: their potential for use in American dairy products. Food Technology .1991; 45, 74- 83

[28]. Perdigon, G., Alvarez, S., Rachid, M., Aguero, G. and Gobbato, N. Immune system stimulation by probiotics. Journal of Dairy Science.1995; 78, 1597-1606.

[29]. Mohammed Saleh Al-Jassir,Bushra Mohammed El Bashir and Syed Khaja Moizuddin.Surveillance of infant feeding practices in Riyadh city.Ann.Saudi.Med.2004;24(2),136-140

[30]. Ogra ,PL., and Welliver,RC.Sr. Effect of early environment on mucosal immunologic homeostasis,subsequent immune responses and disease outcome. Nestle. Nutr. Workshop Ser.Pediatr.Program.2008; 61, 145-181

[31]. Immanuel. The pattern of endogenous eczema in the northern frontier, Kingdom of Suadi Arabia. Annals of Saudi Medicine.1995: Vol 15( 4), 416-418

[32]. Norah Ali Al Shehri.The pattern of feeding in the first six months among infants in Riyadh.Middle east journal of family medicine.2014,12(2),23-25

[33]. Kageyama A, Benno Y, Nakase T. Phylogenetic evidence for the transfer of Eubacterium lentum to the genus Eggerthella as Eggerthella lenta gen.nov., comb. nov.. Int J Syst Bacteriol 1999;49(4):1725-32.

[34]. Oggioni MR, Pozzi G, Valensin PE, Galieni P, Bigazzi C. Recurrent septicemia in an immunocompromised patient due to probiotic strains of Bacillus subtilis. J. Clin. Microbiol. 1998; 36 (1): 325-6

[35]. De La Cochetière MF, Piloquet H, Des Robert C, Darmaun D, Galmiche JP, et al. Early intestinal bacterial colonization and necrotizing enterocolitis in premature infants: the putative role of Clostridium. Pediatr Res.2004; 56: 1-5

[36]. Gerber JS, Glas M, Frank G and Shah SS. Streptococcus bovis Infection in young infants.Pediatr.Infect.Dis.J.2006;25(11):1069-73

[37]. Ryan KJ. and Ray CG(Editors).Sherris Medical Microbiology(4 ${ }^{\text {th }}$ ed).2004;McGraw Hill.

[38]. White B.A.,Labhsetwar S.A.,Mian A.N.,Streptococcus bovis bacteremia and fetal death.Obstet.Gynecol.2002;100(5pt2):1126-9

[39]. Shugui Wang, Lydia Hui Mei Ng, Wai Ling Chow, and Yuan Kun Lee. Infant intestinal Enterococcus faecalis down-regulates inflammatory responses in human intestinal cell lines. World J Gastroenterol. 2008; 14(7): 1067-1076

[40]. Coudron PE,Mayhall CG,Facklam RR,Spadora AC,Lamb VA,Lybrand MR and Dalton HP.Streptococcus faecium outbreak in a neonatal intensive care unit. J Clin Microbiol.1984;20(6):1044-1048

[41]. Ester Sanchez,Giada De Palma,Amalia Capilla,Esther Nova,Tamara Pozo,Gemma Castillejo,Vicente Varea,Ascension Marcos,Jose Antonio Garrote,Isabel Polanco,Ana Lopez,Carmen Ribes-Koninckx,Maria Dolores Garcia-Novo,Carmen Calvo,Luis Ortigosa,Francesc Palau and Yolanda Sanz.Colonization of infant's gut by Bacteroides is influenced by environmental and genet ic factors linked to celiac disease risk. Applied and environmental microbiology.2014;80(23).Published online ahead of print.

[42]. Federica Guaraldi and Guglielmo Salvatori. Effect of breast and formula feeding on gut microbiota shaping in new borns. Frontiers in cellular and infection microbiology.2012; 2:94

[43]. Yoshimi Benno,Ken Sawada and Tomotari Mitsuoka. The intestinal microflora of infants: composition of fecal flora in breast fed infants.Microbiol.Immunol.1984;28(9),975-986

[44]. Balcht, Aldona and Smith, Raymond. Pseudomonas aeruginosa: Infections and Treatment. Informa Health Care. 1994;pp. 83-84

[45]. Ivarsson, AO.,Hernell, H. Stenlund, and Persson, LA. Breastfeeding protects against celiac disease. Am. J. Clin. Nutr. 2002;75:914921. 